\title{
SPATIAL MODELLING OF LOCAL FLOODING FOR HAZARD MITIGATION IN SURAKARTA, INDONESIA
}

\author{
*Alif Noor Anna ${ }^{1}$, Yuli Priyana1, Vidya Nahdhiyatul Fikriyah, Mohd Hairy Ibrahim², Kamarul Ismail², \\ Mareta Suci Pamekar ${ }^{1}$, Ahmad Dzakir Tyas Asshodiq ${ }^{1}$ \\ ${ }^{1}$ Faculty of Geography, Universitas Muhammadiyah Surakarta, Indonesia; ${ }^{2}$ Faculty of Human Sciences, \\ Universiti Pendidikan Sultas Idris, Malaysia
}

*Corresponding Author, Received: 31 Aug. 2021, Revised: 04 Nov. 2021, Accepted: 23 Nov. 2021

\begin{abstract}
Floods are one of hazards that periodically occur in Surakarta, Indonesia. This flooding has caused damage to road infrastructure, disrupted socioeconomic activities of the community, and disturbed road traffic. However, there is no ongoing disaster management to minimize the risk. Mitigation activity is an important component in the disaster management that is needed to minimize the impact of flooding. Spatial analysis and modelling is part of disaster mitigation as it can be used to predict the spatial extent of floods. The purpose of this study is to develop a spatial model of flooding using the rational modification method. The stages in this research include creating flood evaluation model, model validation, and model visualization. This study used secondary data accompanied by field observations. The datasets consist of rainfall data, slope, vegetation cover, soil type, area, surface storage, water infiltration volume, and drainage capacity. All data was then analysed by descriptive quantitative techniques. For the flood modelling, Geographic Information System (GIS) technology was used with two scenarios namely A and B. Based on the results of scenario A with a rainfall intensity of $93.2 \mathrm{~mm} /$ hour, and scenario B with a rainfall intensity of $136.6 \mathrm{~mm} /$ hour, the flooding occurred throughout Surakarta. In addition, the results of the Focus Group Discussion with the Public Works and Spatial Planning Office of Surakarta City found that hydrological data modelling had not been utilized in making drainage channels for flood prevention, which eventually resulted in floods still occurring during the rainy season.
\end{abstract}

Keywords: Disaster mitigation, Spatial modelling, Flood inundation, Flood scenario, Surakarta City

\section{INTRODUCTION}

Flood inundation in the city of Surakarta often occurs in the rainy season, due to the high volume and intensity of rainfall. The capacity of the drainage system is inadequate to deal with these high flows. This flooding was also triggered by community activities such as littering and land conversion [1]. Inundation floods occur because the high volume of water flowing in an area exceeds its capacity [2-7]. This phenomenon causes negative impacts, such as road damage, disrupted socioeconomic community activities, and traffic congestion [8-11].

One of the efforts to minimize the impact of inundation is to perform disaster mitigation. Mitigation activities are one of the important components in dealing with inundation flood disasters as it is part of the early warning system. Indonesian Government Regulation Number 21 of 2008 states that disaster mitigation is a series of efforts to reduce disaster risk, through physical development, awareness, and capacity building. Apart from flood vulnerability mapping [12] and risk assessment [13], therefore, modelling studies of inundation flooding is important part of efforts to deal with these disaster events.
Inundation flood mitigation can be done by hydrological modeling. There are various types of modeling in hydrology that can be applied to inundation floods, including: stochastic models, probability models, conceptual models based on actual conditions, parametric models, and deterministic models [2]. This study will adopt a conceptual model based on the real situation using the rational method. This method was developed based on the specific assumption that the rain that occurs has a uniform and even intensity throughout the watershed for at least the same time of concentration $\left(\mathrm{t}_{\mathrm{c}}\right)$ as the watershed.

One of the analytical techniques that can be used for inundation flood mitigation is to use spatial analysis, specifically by making spatial modeling of inundation floods [4]. The result of this modeling is a map of potential inundation floods [14-15]. This model is obtained from the calculation between runoff discharge minus the volume of infiltration and regional drainage capacity. Meanwhile, for the calculation of the runoff discharge, the runoff coefficient uses the Cooks method [16-19]. Therefore, flood inundation can occur if the discharge value is greater than the infiltration volume and drainage capacity.

Spatial modeling of flood inundation in 
Surakarta City can be done by utilizing Geographic Information System (GIS) technology. GIS is a technology for inputting, managing, manipulating, and analyzing spatial and non-spatial data originating from the real world [20]. In this study, GIS was used to process, analyze, and create a spatial model of flood inundation through overlay and measurement functions.

Taking all the motivation above, this study aims to create a spatial model of inundation based on rainfall intensity scenarios using rational method in the city of Surakarta. This research is important because it can be used as consideration for spatial planning and the development of urban drainage systems for flood prevention.

\section{RESEARCH SIGNIFICANCE}

Study of flood inundation potential is essential as a contribution to disaster mitigation. Because Surakarta city is located in an intermountain plain, where the region is prone to flood inundation. Therefore, this study intends to model the potential for flooding in Surakarta using a geospatial approach. Several physical parameters were integrated and used as inputs for the model, namely land use, rainfall, slope, soil, infiltration, and drainage capacity. The resulted model would provide information on location of flooded area which is helpful for local government and disaster management institution in tackling flood in Surakarta.

\section{METHODOLOGY}

\subsection{Study Area}

Surakarta City is located between $110^{\circ} 46^{\prime} 10^{\prime \prime}$ to $110^{\circ} 51^{\prime 2} 25^{\prime \prime}$ East longitude and $7^{\circ} 32^{\prime} 13^{\prime \prime}$ to $7^{\circ} 35^{\prime} 12^{\prime \prime}$ North latitude, covering the area of $44.04 \mathrm{~km}^{2}$. It has certain characteristics including: (a) inundation floods in rainy season which bring negative impact on the community, (b) the basin morphology of Surakarta City makes it to be in a floodplain area, and (c) flood-prone area [21]. Surakarta City is in a depression zone and an intermountain plain surrounded by Lawu Volcano, Merapi Volcano, Merbabu Volcano, Kendeng Hills and Southern Mountains. The area is in the form of young volcanic deposits from the Lawu Volcano, Merapi Volcano and Merbabu Volcano as well as sediment from the Kendeng Hills and Southern Hills. The northern city of Surakarta is part of the Kendeng Hills. The area is a lowland area with an altitude of only 80-120 meters above sea level and categorized into type D (slightly wet) climate, giving implication to the potential of flooding. Soil types in Surakarta includes: (a) associations of dark gray grumusol and reddish brown mediterranean, (b) dark brown mediterranean, (c) grayish brown alluvial, and (d) gray regosol.

Surakarta city has macro and micro drainage system. The macro system includes: (a) Kijing River, (b) Pelemwulung River (Wingko River and Tanggul River), (c) Pepe River, (d) Sumber River and (e) Anyar River which is a canal from Pepe River and Sumber River. The estuaries of these rivers are at Bengawan Solo River. The micro system includes: (a) secondary channels including the micro system, namely Kali Pepe Hilir and Kali Jenes.

\subsection{Spatial Modelling of Flood}

In this study, several data were used, including land use or vegetation cover, soil type, slope, surface storage, runoff coefficient (C), rainfall distribution (I), area, runoff discharge (Qp), infiltration capacity volume (R), and regional drainage capacity (D). Next, three flood parameters were extracted which are runoff discharge (Qp), infiltration volume (R), and drainage capacity (D). Those parameters were then integrated in ArcGIS to obtain the potential inundation flood (Fig.1). The potential flood was also classified using the scheme presented in Table 1. Figure 2 shows the all stages performed in this study.

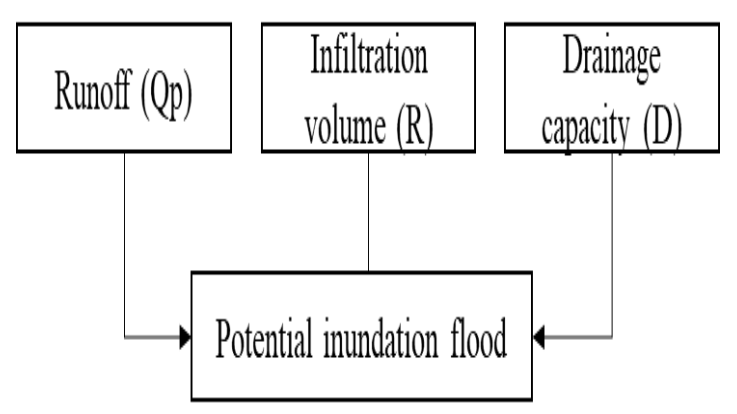

Fig.1 Research scheme

Table 1 Classification of potential flood inundation in Surakarta

\begin{tabular}{ll}
\hline \multicolumn{1}{c}{ Analysis } & \multicolumn{1}{c}{ Description } \\
\hline Qp - $(\mathrm{R}+\mathrm{D})=(+)$ positive or $\mathrm{Qp}>(\mathrm{R}+\mathrm{D})$ & Potential to flood \\
$\mathrm{Qp}-(\mathrm{R}+\mathrm{D})=(-)$ negative or $\mathrm{Qp}<(\mathrm{R}+\mathrm{D})$ & $\begin{array}{l}\text { Not potential to } \\
\text { flood }\end{array}$ \\
$\mathrm{Qp}-(\mathrm{R}+\mathrm{D})=(0)$ or $\mathrm{Qp}=(\mathrm{R}+\mathrm{D}$ & $\begin{array}{l}\text { Small potential to } \\
\text { flood }\end{array}$ \\
\hline
\end{tabular}

Furthermore, the inundation flood modelling in Surakarta City was conducted in two scenarios (A and B). Scenario A used data of maximum rainfall intensity that occur in 2020, while scenario B used data of maximum rainfall intensity that occurs in 2021. 


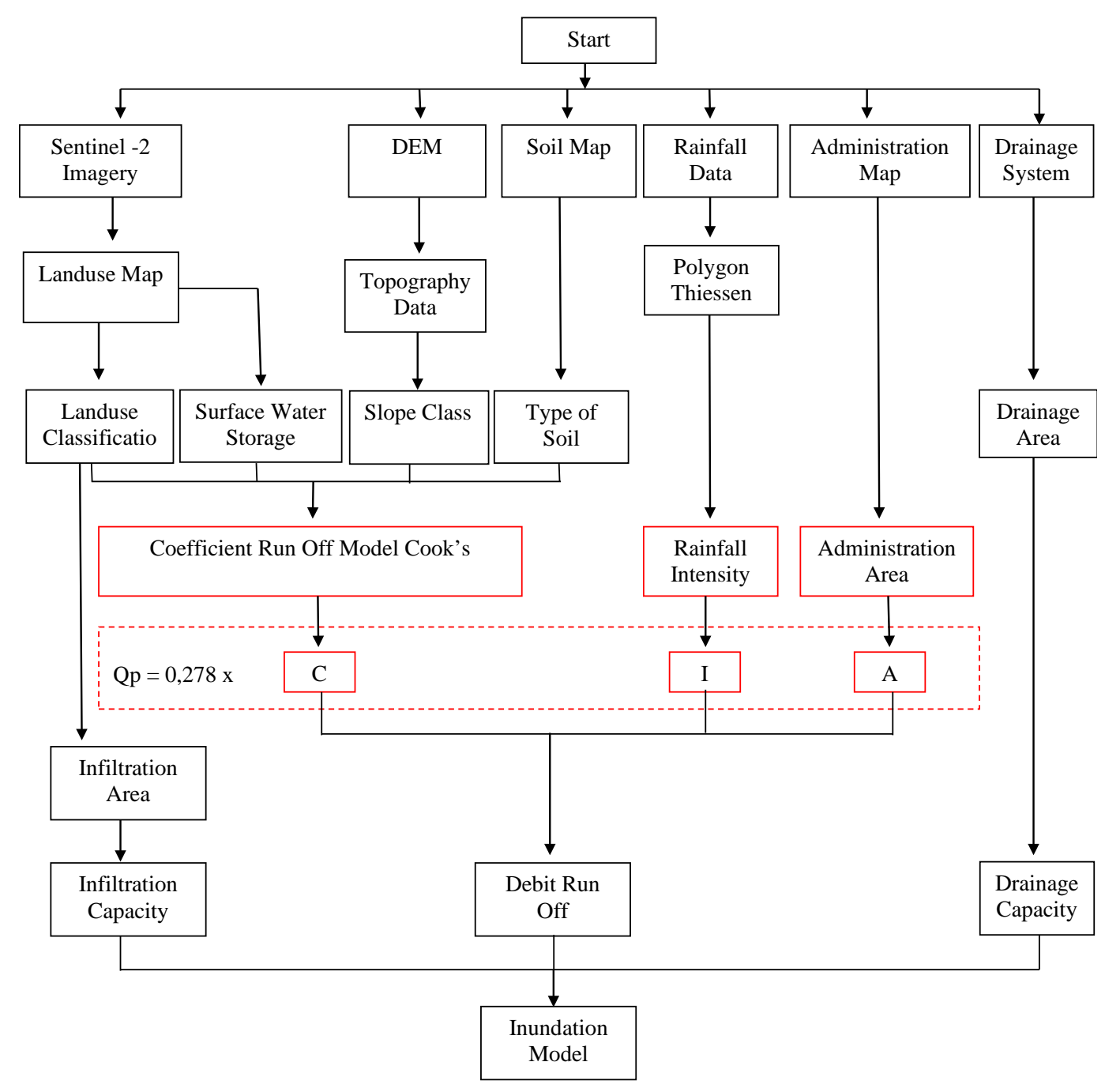

Fig.2 Research workflow

\section{RESULT AND DISCUSSION}

\subsection{Runoff Coefficient (C)}

The parameters used to calculate the runoff coefficient with the Hassing model are topography, soil, vegetation, and surface storage parameters (Table 2). The highest runoff coefficient value based on Cook's model is in Jebres at 25.958, while the lowest score is in Banjarsari at 17.656. A high score indicates that the potential for runoff is high so that it will have an impact on the potential for puddles. The factors that have the most impact on the runoff coefficient in the research area are topography and vegetation.

Based on the classification of Cook's Model, the low runoff coefficients range is $0-25$, moderate $>$ 25-50, and high > 50. Therefore, the runoff condition in Surakarta were categorized as low (Banjarsari, Pasar Kliwon, Laweyan, and Serengan) and moderate (Jebres).

\subsection{Rainfall Intensity (I)}

The intensity of rainfall was calculated using the Thiessen polygon method from two rainfall stations around the city of Surakarta (Pabelan Station and Jurug Station 2). Rainfall data at both stations is based on monthly average rainfall data in 2020. The average amount of rainfall at Pabelan Station in 2020 is $45.41 \mathrm{~mm} /$ hour. Meanwhile, the average monthly rainfall at Jurug 2 Station is 32.78 $\mathrm{mm} /$ hour. In detail about the calculation results can be seen in Table 3.

The results showed that the highest average rainfall intensity is in Pasar Kliwon and Jebres Subdistricts at $32.78 \mathrm{~mm} /$ hour. Meanwhile, the lowest average rainfall intensity is in Serengan Sub-district at $17.73 \mathrm{~mm} /$ hour. The high and low intensity of the average rainfall is largely determined by the rainfall itself and also the coverage of the rainfall station. The implication of high rainfall will have an impact on increasing the potential for runoff and the potential for flooding. 
Table 2 Coefficient of runoff (C)

\begin{tabular}{lcccrc}
\hline Sub-district & slope & $\begin{array}{c}\text { Runoff coefficient (C) } \\
\text { soil }\end{array}$ & $\begin{array}{c}\text { Vegetation } \\
\text { cover }\end{array}$ & $\begin{array}{c}\text { Surface } \\
\text { storage }\end{array}$ & Total \\
\hline Banjarsari & 6.89 & 3.95 & 3.83 & 3.00 & 17.66 \\
Jebres & 9.70 & 7.50 & 4.84 & 3.92 & 25.96 \\
Pasar Kliwon & 6.04 & 3.60 & 4.83 & 3.75 & 18.23 \\
Laweyan & 5.38 & 5.00 & 4.91 & 3.75 & 19.04 \\
Serengan & 5.14 & 2.50 & 6.59 & 5.00 & 19.23 \\
\hline
\end{tabular}

Table 3 Rainfall intensity (I)

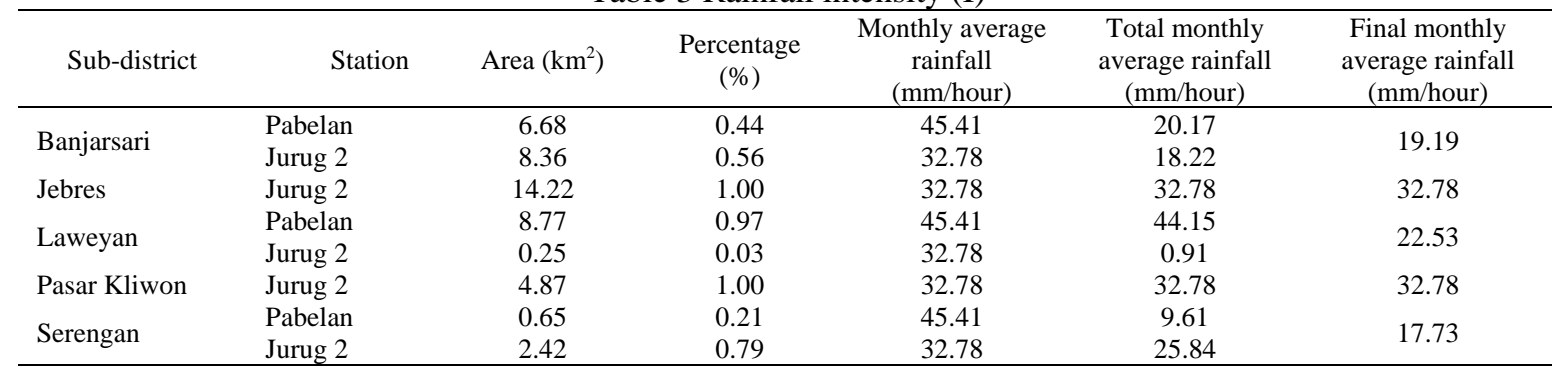

\subsection{Area (A)}

The area in this study was obtained from the Central Statistics Agency (BPS) for the City of Surakarta as stated in the Surakarta publication report in Figures 2021. The total area in Surakarta City is $44.04 \mathrm{~km}^{2}$ (Table 4).

Table 4 Area of sub-district in Surakarta

\begin{tabular}{lc}
\hline Sub-district & Area $\left(\mathrm{km}^{2}\right)$ \\
\hline Laweyan & 8.64 \\
Serengan & 3.19 \\
Pasar Kliwon & 4.82 \\
Jebres & 12.58 \\
Banjarsari & 14.81 \\
Total & 44.04 \\
\hline Source: BPS Surakarta, 2021 &
\end{tabular}

\subsection{Discharge Runoff}

The runoff discharge is calculated by using the equation formula of the rational method. Meanwhile, the runoff coefficient used the Cook's model. Equation (1) is used to calculate the runoff discharge with the rational method:

$Q p=0.278 . C . I . A$

Where,

Qp : peak discharge $\left(\mathrm{m}^{3} / \mathrm{sec}\right)$

$\mathrm{C} \quad$ : runoff coefficient

I : rainfall intensity (mm/hour)

A : area $\left(\mathrm{km}^{2}\right)$

Based on Table 5, it can be seen that the highest runoff discharge value based on the classification of the runoff coefficient of the Cook's model is in Jebres Sub-district of 2,975.81 $\mathrm{m}^{3} / \mathrm{s}$.
Meanwhile, the lowest runoff discharge value is in Serengan Sub-district at $299.37 \mathrm{~m}^{3} / \mathrm{s}$.

Table 5 Peak discharge from Cook’s Model

\begin{tabular}{|c|c|c|c|c|c|}
\hline $\begin{array}{c}\text { Sub- } \\
\text { district }\end{array}$ & & $\begin{array}{c}\mathrm{C} \\
\left(\mathrm{m}^{3} / \mathrm{s}\right)\end{array}$ & $\begin{array}{c}\mathrm{I} \\
\text { (mm/hour) }\end{array}$ & $\begin{array}{c}\mathrm{A} \\
\left(\mathrm{km}^{2}\right)\end{array}$ & $\begin{array}{c}\text { Qp } \\
\left(\mathrm{m}^{3} / \mathrm{s}\right)\end{array}$ \\
\hline Banjarsari & & 17.656 & 19.19 & 14.81 & $1,394.98$ \\
\hline Jebres & 0770 & 25.958 & 32.78 & 12.58 & 2,975.81 \\
\hline Pasar & 0.278 & 18.225 & 32.78 & 4.82 & \\
\hline Kliwon & & & & & 800.51 \\
\hline Serengan & & 19.04 & 17.73 & 3.19 & 299.37 \\
\hline Laweyan & & 19.233 & 22.53 & 8.64 & $1,040.80$ \\
\hline
\end{tabular}

Areas that have a high runoff discharge indicate that the area has the potential for inundation to occur. One of the factors causing the high potential for runoff discharge is the high runoff coefficient value and the intensity of the rain that occurs. This is in line with the previous studies [22-23] which states that the intensity of rainfall and vegetation has an impact on the discharge conditions of an area. The higher the rainfall accompanied by the increased growth of the built-up area, the higher the potential for runoff discharge.

\subsection{Infiltration Volume Capacity (R)}

The catchment area data can be obtained from the calculation of features of non-built land use types minus the area of water body features (rivers, reservoirs, and so on). Furthermore, to generate the infiltration capacity parameter feature, the infiltration volume data derived from secondary data, is inputted into the infiltration area feature that has been created. Thus, the feature of the infiltration area will represent the capacity of the existing infiltration volume. Details of the calculation results can be seen in Table 6 . 
Table 6 Infiltration volume capacity in Surakarta

\begin{tabular}{lcccc}
\hline Sub-district & $\begin{array}{c}\text { Non } \\
\text { built-up } \\
\left(\mathrm{km}^{2}\right)\end{array}$ & $\begin{array}{c}\text { Water } \\
\text { body } \\
\left(\mathrm{km}^{2}\right)\end{array}$ & $\begin{array}{c}\text { Infiltration } \\
\text { capacity } \\
\left(\mathrm{km}^{2}\right)\end{array}$ & $\begin{array}{c}\text { Volume } \\
\left(\mathrm{m}^{3}\right)\end{array}$ \\
\hline Banjarsari & 0.706627 & 0.295221 & 0.41 & 41 \\
Jebres & 0.770426 & 0.429375 & 0.34 & 34 \\
Pasar Kliwon & 0.127816 & 0.07217 & 0.06 & 6 \\
Serengan & 0.026254 & 0.015021 & 0.01 & 1 \\
Laweyan & 0.297037 & 0.009915 & 0.29 & 29 \\
\hline
\end{tabular}

Table 6 shows that the highest infiltration volume capacity is in Banjarsari Sub-district of 41 $\mathrm{m}^{3}$ and the lowest capacity is in Serengan Subdistrict of $1 \mathrm{~m}^{3}$. The larger the infiltration volume, the smaller the inundation will occur. The small infiltration volume indicates that the area is an area that has a high built-up area so it is difficult to absorb water into the ground.

\subsection{Drainage Capacity (D)}

First, drainage channel features are needed to produce regional drainage capacity data, drainage channels are obtained from digitizing the Surakarta drainage map. Then secondary data in the form of regional drainage channel capacity data is inputted into the attribute feature that has been created. Details of the drainage capacity of Surakarta City can be seen in Table 7 .

Table 7 Drainage Capacity in Surakarta

\begin{tabular}{|c|c|c|c|}
\hline SubDistrict & $\begin{array}{c}\text { Drainage system } \\
\text { (river) }\end{array}$ & $\begin{array}{c}\text { Area } \\
\left(\mathrm{km}^{2}\right)\end{array}$ & $\begin{array}{c}\text { volume } \\
\left(\mathrm{m}^{3}\right)\end{array}$ \\
\hline \multirow{4}{*}{ Banjarsari } & Anyar & 4.623 & \multirow{4}{*}{147.28} \\
\hline & Gajah Putih & 3.031 & \\
\hline & Pepe Hilir & 3.199 & \\
\hline & Pepe Hulu & 3.875 & \\
\hline \multirow{3}{*}{ Jebres } & Bengawan Solo & 4.343 & \multirow{3}{*}{145.18} \\
\hline & Anyar & 8.314 & \\
\hline & Pepe Hilir & 1.861 & \\
\hline Laweyan & Gajah Putih & 1.588 & 158.8 \\
\hline \multirow{5}{*}{ Pasar Kliwon } & Bengawan Solo & 1.586 & \multirow{5}{*}{916.5} \\
\hline & Jenes & 2.759 & \\
\hline & Pepe Hilir & 1.691 & \\
\hline & Tanggul & 3.122 & \\
\hline & Wingko & 0.007 & \\
\hline \multirow{3}{*}{ Serengan } & Jenes & 1.594 & \multirow{3}{*}{713.7} \\
\hline & Tanggul & 5.117 & \\
\hline & Wingko & 0.426 & \\
\hline
\end{tabular}

Source: Public Works and Spatial Planning Office of Surakarta, 2021

Based on Table 7, it is observed that the highest drainage capacity in Surakarta City is in Pasar Kliwon of $916.5 \mathrm{~m}^{3}$. Meanwhile, the lowest drainage capacity is in Jebres, which is $145.18 \mathrm{~m}^{3}$. A high drainage capacity can minimize the occurrence of inundation floods and conversely a low drainage capacity causes an area to have the potential for inundation to occur. Based on the field survey, it is found that the drainage function in Surakarta is currently less than optimal. This is due to the lack of periodic maintenance activities carried out by the Surakarta Government. For example, the drainage conditions found a lot of garbage, both plastic and leaves that had piled up. If this is not addressed, the drainage capacity will certainly decrease.

\subsection{Flood Inundation Modelling (F)}

The flood inundation modeling in this study was calculated by referring to the calculation of three inundation flood parameters, namely runoff discharge (Qp), infiltration volume capacity (R), and regional drainage capacity (D). Furthermore, the potential for flood inundation is obtained through the overlay technique of the three parameters. Equation (2) is used to calculate the potential for flooding in the study area is as follows:

$$
\boldsymbol{F}=\boldsymbol{Q p}-(\boldsymbol{R}+\boldsymbol{D})
$$

where:

$\begin{array}{ll}\text { F } & \text { : Flood inundation (local flood) } \\ \text { Qp } & \text { : Surface runoff } \\ \text { R } & \text { : Infiltration capacity } \\ \text { D } & \text { : Drainage capacity }\end{array}$

According to Table 8, the result of flood modelling using Cook's method in Surakarta City had a positive $(+)$ and negative (-) values. The positive values indicate that the area is potentially flooded. The sub-districts that have the potential to be inundated under these conditions including Banjarsari $\left(14.81 \mathrm{~km}^{2}\right)$, Jebres $\left(12.58 \mathrm{~km}^{2}\right)$, and Laweyan (8.64 $\mathrm{km}^{2}$ ) (Fig. 3). The infiltration and drainage capacity in these regions are considered no longer able to accommodate the existing debit amount. Meanwhile, Pasar Kliwon sub-districts and Serengan were not flooded, indicating that the current condition of infiltration volume and drainage capacity is still able to accommodate the existing discharge.

The potential of inundation flooding that occurs in Surakarta City is currently caused by the high potential for discharge and the lack of water catchment areas. It is observed that the potential flood occurs in areas with the following characteristics: (a) high rainfall intensity (>60 $\mathrm{mm} /$ hour), a slope of 5-10\%, (b) built-up areas, (c) soil type of dark gray grumusol, Mediterranean, and dark brown Mediterranean, and (d) poor drainage system. These findings therefore support the prior study [24], who stated that the causes of inundation floods are generally high rainfall intensity, less optimal drainage capacity, and high levels of building density in areas prone to flooding. 


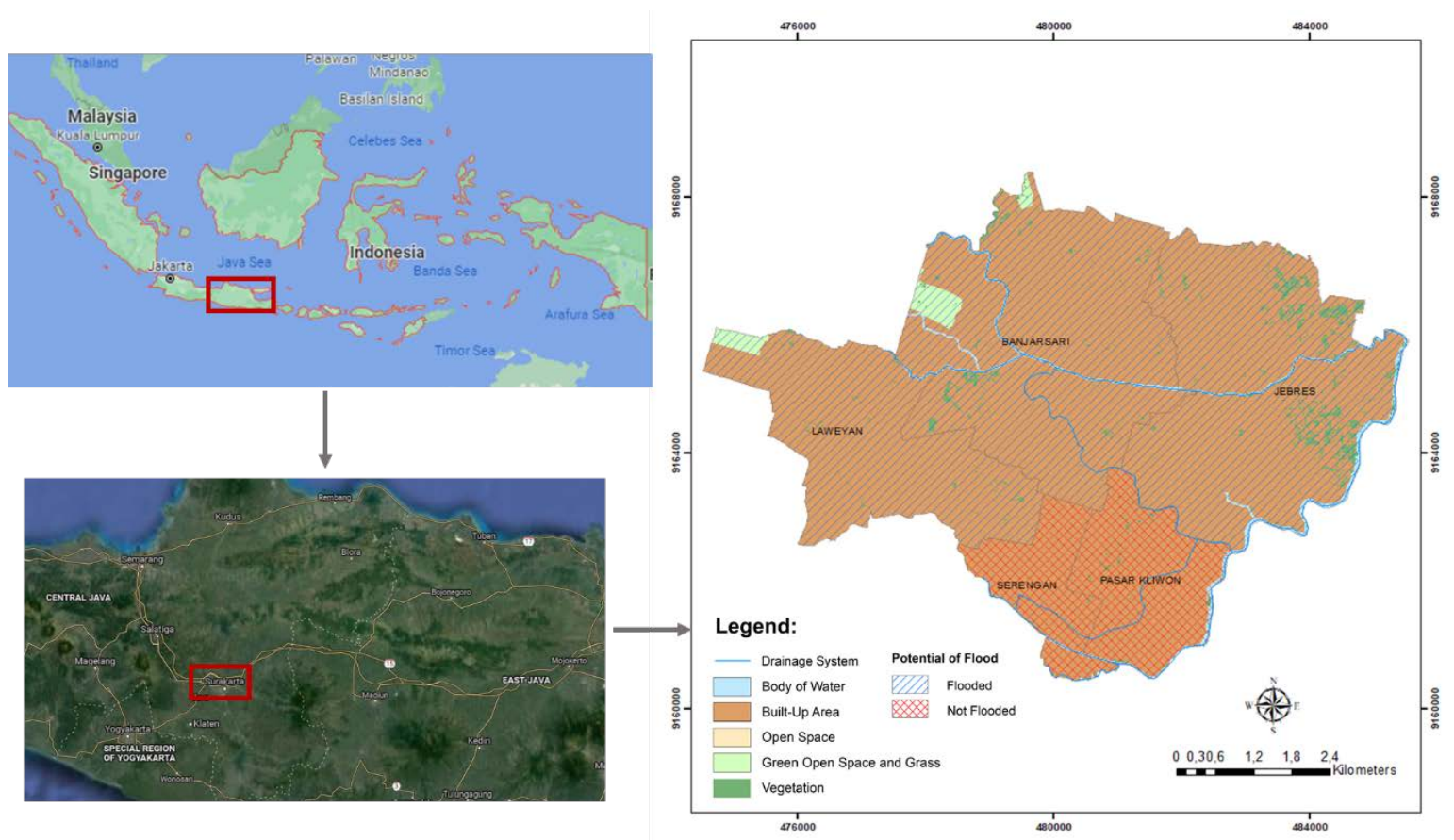

Fig. 3 Potential Flood Inundation in Surakarta

Table 8 Flood inundation model using Cook’s method

\begin{tabular}{|c|c|c|c|c|c|c|}
\hline Sub-district & $\begin{array}{c}\text { runoff } \\
\text { discharge } \\
\text { (Qp) }\end{array}$ & $\begin{array}{l}\text { infiltration } \\
\text { volume } \\
\text { (R) }\end{array}$ & $\begin{array}{l}\text { drainage } \\
\text { capacity } \\
\text { (D) }\end{array}$ & [Qp-(R+D)] & Description & $\begin{array}{c}\text { Area } \\
\left(\mathrm{km}^{2}\right)\end{array}$ \\
\hline Banjarsari & $1,394.98$ & 41 & 147.28 & $1,206.70$ & Flooded & 14.81 \\
\hline Jebres & 2,975.81 & 34 & 145.18 & $2,796.63$ & Flooded & 12.58 \\
\hline Pasar Kliwon & 800.51 & 6 & 916.5 & -121.99 & Not flooded & 4.82 \\
\hline Serengan & 299.37 & 1 & 713.7 & -415.33 & Not flooded & 3.19 \\
\hline Laweyan & $1,040.80$ & 29 & 158.8 & 853.00 & Flooded & 8.64 \\
\hline
\end{tabular}

\subsection{Flood Inundation Model Scenarios}

In this study, the flood inundation model scenario is divided into two, scenario A and B, in which different in the rainfall intensity data. This is because rainfall is the main parameter that causes flooding in the area. Scenario A used maximum rainfall that occurred in 2020, which is $93.2 \mathrm{~mm} /$ hour. While scenario $\mathrm{B}$ used maximum rainfall in 2021, which is 136.6 $\mathrm{mm} /$ hour. The coefficient value to create the scenario is from the Cook's model. In detail, the results of both scenarios can be seen in Table 9 and Table 10.

Table 9 Result of flood model in scenario A

\begin{tabular}{lcccccccccc}
\hline Sub-district & constant & $\mathrm{C}$ & $\mathrm{I}$ & $\mathrm{A}$ & $\mathrm{Qp}$ & $\mathrm{R}$ & $\mathrm{D}$ & $(\mathrm{R}+\mathrm{D})$ & $\begin{array}{c}\text { [Qp- } \\
(\mathrm{R}+\mathrm{D})\end{array}$ & Description \\
\hline Banjarsari & 0.278 & 17.656 & 93.2 & 14.81 & $6,774.98$ & 41 & 147.28 & 188.28 & $6,586.70$ & Flooded \\
Jebres & 0.278 & 25.958 & 93.2 & 12.58 & $8,460.82$ & 34 & 145.18 & 179.18 & $8,281.64$ & Flooded \\
Pasar Kliwon & 0.278 & 18.225 & 93.2 & 4.82 & $2,276.02$ & 6 & 916.5 & 922.50 & $1,353.52$ & Flooded \\
Serengan & 0.278 & 19.04 & 93.2 & 3.19 & $1,573.69$ & 1 & 713.7 & 714.70 & 858.99 & Flooded \\
Laweyan & 0.278 & 19.233 & 93.2 & 8.64 & $4,305.48$ & 29 & 158.8 & 187.80 & $4,117.68$ & Flooded \\
\hline
\end{tabular}


Table 10 Result of flood model in scenario B

\begin{tabular}{|c|c|c|c|c|c|c|c|c|c|c|}
\hline Sub-district & constant & $\mathrm{C}$ & I & A & $\mathrm{Qp}$ & $\mathrm{R}$ & $\mathrm{D}$ & $(\mathrm{R}+\mathrm{D})$ & $\begin{array}{c}{[\mathrm{Qp}-} \\
(\mathrm{R}+\mathrm{D})\end{array}$ & Description \\
\hline Banjarsari & 0.278 & 17.656 & 136.6 & 14.81 & $9,929.85$ & 41 & 147.28 & 188.28 & $9,741.57$ & Flooded \\
\hline Jebres & 0.278 & 25.958 & 136.6 & 12.58 & $12,400.73$ & 34 & 145.18 & 179.18 & $12,221.55$ & Flooded \\
\hline Pasar Kliwon & 0.278 & 18.225 & 136.6 & 4.82 & 3,335.88 & 6 & 916.5 & 922.50 & $2,413.38$ & Flooded \\
\hline Serengan & 0.278 & 19.04 & 136.6 & 3.19 & $2,306.50$ & 1 & 713.7 & 714.70 & $1,591.80$ & Flooded \\
\hline Laweyan & 0.278 & 19.233 & 136.6 & 8.64 & $6,310.39$ & 29 & 158.8 & 187.80 & $6,122.59$ & Flooded \\
\hline
\end{tabular}

Based on Table 9 and Table 10, it can be seen from both scenarios, that Surakarta is flooded throughout the regions. This is actually in line with the results of the Focus Group Discussion (FGD) activity that has also been carried out with stakeholders to confirm the findings. It was found that Surakarta has a flat topography, minimal water infiltration conditions, and non-optimal drainage. When the high rainfall intensity occurs ( $>60$ $\mathrm{mm} /$ hour), then the area will be flooded. The occurrence of inundation floods will occur evenly in all sub-districts, which are Banjarsari, Jebres, Pasar Kliwon, Serengan, and Laweyan.

\section{CONCLUSION}

In this study, flood modelling has been carried out in Surakarta. The results indicate that the area has the potential to inundate during the rainy season, especially in Banjarsari, Jebres, and Laweyan subdistricts. Based on the results of scenario A with rainfall intensity of $93.2 \mathrm{~mm} /$ hour, and scenario B with rainfall intensity of $136.6 \mathrm{~mm} /$ hour, flood inundation can occur throughout Surakarta. The potential for inundation flooding occurs in areas with the following characteristics: (a) high rainfall intensity (>60 mm/hour), (b) slope of $5-10 \%$, (c) built-up areas, (d) soil type in associations of dark gray grumusol, Mediterranean, and dark brown Mediterranean soil, and (e) poor drainage system. The findings of this study are also supported with the results of focus group discussion with the Surakarta City Public Works and Spatial Planning Office where the current inundation flooding was caused by factors of rainfall intensity, land use, and poor drainage system planning.

\section{ACKNOWLEDGMENTS}

This research was funded by HIT Program in Faculty of Geography, Universitas Muhammadiyah Surakarta (UMS). We gratefully acknowledge the anonymous reviewers who give constructive feedbacks.

\section{REFERENCES}

[1] Sulaeman, A., Suhartanto, E., \& Sumiadi, S. (2017). Analisis Genangan Banjir Akibat
Luapan Bengawan Solo Untuk Mendukung Peta Risiko Bencana Banjir Di Kabupaten Bojonegoro. Jurnal Teknik Pengairan, 8(2), 146-157.

https://doi.org/10.21776/ub.pengairan.2017. 008.02.1

[2] Harisuseno, D., Bisri, M., Yudono, A., \& Klojen, K. (2014). Model Hidrologi Di Wilayah Perkotaan. Journal of Environmental Engineering \& Sustainable Technology.

[3] Jamali, B., Löwe, R., Bach, P. M., Urich, C., Arnbjerg-Nielsen, K., \& Deletic, A. (2018). A rapid urban flood inundation and damage assessment model. Journal of Hydrology, 564, 1085-1098. https://doi.org/10.1016/j.jhydrol.2018.07.06 4

[4] Liu, C., Li, Y., \& Li, J. (2017). Geographic information system-based assessment of mitigating flash-flood disaster from green roof systems. Computers, Environment and Urban Systems. https://doi.org/10.1016/j.compenvurbsys.20 17.04.008

[5] Saksena, S., \& Merwade, V. (2015). Incorporating the effect of DEM resolution and accuracy for improved flood inundation mapping. Journal of Hydrology. https://doi.org/10.1016/j.jhydrol.2015.09.06 9

[6] Saputro, D. A. T., Ismoyo, M. J., \& ... (2014). Perencanaan Drainase Perkotaan di Kota Nanga Bulik Kabupaten Lamandau Provinsi Kalimantan Tengah. Universitas Brawijaya Malang.

[7] Yin, J., Yu, D., Yin, Z., Liu, M., \& He, Q. (2016). Evaluating the impact and risk of pluvial flash flood on intra-urban road network: A case study in the city center of Shanghai, China. Journal of Hydrology. https://doi.org/10.1016/j.jhydrol.2016.03.03 7

[8] Handoyo, G., Suryoputro, A. A. D., \& Subardjo, P. (2016). Genangan Banjir Rob Di Kecamatan Semarang Utara. Jurnal Kelautan Tropis, 19(1), 55. https://doi.org/10.14710/jkt.v19i1.601

[9] Hanie, M. Z., Tarigan, A. P. M., \& Khair, H. 
(2017). Analisis Mitigasi Banjir di Daerah Aliran Sungai Babura Berbasis Sistem Informasi Geografis (SIG). Jurnal Dampak. https://doi.org/10.25077/dampak.14.1.2332.2017

[10] Priyana, Y., Anna, A. N., \& Sigit, A. A. (2014). Model Simulasi Luapan Banjir Sungai Bengawan Solo untuk Optimalisasi Kegiatan Tanggap Darurat Bencana Banjir. Forum Geografi.

[11] Putra Susila, I. B. K., Nurweda Putra, I. D. N., \& Wira Buana, P. (2017). Rancang Bangun Aplikasi Analisa Pola Hujan Penyebab Banjir Di Jakarta. Jurnal Ilmiah Merpati (Menara Penelitian Akademika Teknologi Informasi), 11. https://doi.org/10.24843/JIM.2017.v05.i03. p01

[12] Ibrahim, N.F., Zardari, N.H., Shirazi, S.M., Haniffah, M.R.B.M., Talib, S.M., Yusop, Z., Yusoff, S.M.A.B.M., 2017. Identification of vulnerable areas to floods in Kelantan River sub-basins by using flood vulnerability index. Int. J. GEOMATE 12, 107-114. https://doi.org/10.21660/2017.29.11110

[13] Farid, M., Gunawan, B., Badri Kusuma, M.S., Habibi, S.A., Yahya, A., 2020. Assessment of flood risk reduction in Bengawan Solo River: A case study of Sragen Regency. Int. J. GEOMATE 18, 229-234. https://doi.org/10.21660/2020.70.18010

[14] Hardiyanto, H., Isnanto, R. R., \& Windasari, I. P. (2016). Pembuatan Aplikasi Augmented Reality Siklus Hidrologi sebagai Media Pembelajaran Berbasis Android. Jurnal Teknologi Dan Sistem Komputer. https://doi.org/10.14710/jtsiskom.4.1.2016. 159-166

[15] Putiamini, S., Kusratmoko, E., \& Syamsudin, F. (2017). Pemodelan kejadian banjir daerah aliran sungai Ciliwung hulu dengan menggunakan data radar. Jurnal Geografi Lingkungan Tropik, 1(1). https://doi.org/10.7454/jglitrop.v1i1.3

[16] Avanzi, F., De Michele, C., Morin, S., Carmagnola, C. M., Ghezzi, A., \& Lejeune, Y. (2016). Model complexity and data requirements in snow hydrology: seeking a balance in practical applications. Hydrological Processes, 30(13), 2106-2118. https://doi.org/10.1002/hyp.10782

[17] Engel, M., Penna, D., Bertoldi, G., Dell'Agnese, A., Soulsby, C., \& Comiti, F. (2016).
Identifying run-off contributions during melt-induced run-off events in a glacierized alpine catchment. Hydrological Processes, 30(3), https://doi.org/10.1002/hyp.10577

[18] Khare, D., Patra, D., Mondal, A., \& Kundu, S. (2017). Impact of landuse/land cover change on run-off in the catchment of a hydro power project. Applied Water Science, $7(2)$, $787-800$. https://doi.org/10.1007/s13201-015-0292-0

[19] Suhardi, Munir, A., Faridah, S. N., Waris, A., Sapsal, M. T., \& Samsuar. (2019). Use of The Zero Run-Off System to Minimaze of Surface Runoff on Cacao Land. IOP Conference Series: Earth and Environmental Science, 355, 012104. https://doi.org/10.1088/17551315/355/1/012104

[20] Ariyora, Y., Budisusanto, Y., \& Prasasti, I. (2015). Pemanfaatan Data Penginderaan Jauh dan SIG untuk Analisa Banjir (Studi Kasus: Banjir Provinsi DKI Jakarta). Geoid, 10(02), 137-146.

[21] Lumban Batu, J. A. J., \& Fibriani, C. (2017). Analisis Penentuan Lokasi Evakuasi Bencana Banjir Dengan Pemanfaatan Sistem Informasi Geografis Dan Metode Simple Additive Weighting. Jurnal Teknologi Informasi Dan Ilmu Komputer. https://doi.org/10.25126/jtiik.201742315

[22] Wei, Zl., Sun, Hy., Xu, Hd. et al. The effects of rainfall regimes and rainfall characteristics on peak discharge in a small debris flow-prone catchment. J. Mt. Sci. 16, 1646-1660 (2019). https://doi.org/10.1007/s11629-018-5260-3

[23] Bingqin Zhao, Lun Zhang, Zhenyao Xia, Wennian Xu, Lu Xia, Yongzhe Liang, Dong Xia, "Effects of Rainfall Intensity and Vegetation Cover on Erosion Characteristics of a Soil Containing Rock Fragments Slope", Advances in Civil Engineering, vol. 2019, Article ID 7043428, 14 pages, 2019. https://doi.org /10.1155/2019/7043428

[24] Morita, M. Flood Risk Impact Factor for Comparatively Evaluating the Main Causes that Contribute to Flood Risk in Urban Drainage Areas. Water 2014, 6, 253-270. https://doi.org/10.3390/w6020253

Copyright (C) Int. J. of GEOMATE All rights reserved, including making copies unless permission is obtained from the copyright proprietors. 